\title{
SCOPE OF MEANING AS A FACTOR OF PRECEDENT NAME TRANSLATION
}

\section{G.V. Tashchenko, PhD (Kharkiv)}

The article deals with the dependence of the precedent name translation on the bond joining it to its source and, correspondingly, to the mental image the onym activates in a particular context. While certain precedent names function in a cultural medium independently becoming symbols of various features, others can be decoded only against the background of the text or the situation they are derived from. A specific category of precedent names is represented by those accompanied by a complex of stereotypical associations attached to them in the corresponding society but not directly connected with the source, i. e. the culture-specific mental image prevails over the origin. The category a precedent name falls under constitutes an essential factor of translation, since it determines the need for and the scope of compensation the translator shall provide if the onym proves irrelevant for the target culture. Extra-textual commentaries form the most productive method of translation, as they give the opportunity not only to avoid interpretation gaps but also to preserve cultural specificity of the original. However, such commentaries are most efficient if they are as concise as possible, giving maximum information necessary for the name decoding in a particular message, avoiding both insufficiency and excessiveness.

Key words: mental image, method of translation, precedent name, precedent situation, precedent text, source culture, target culture.

Тащенко Г. В. Обсяг значення як чинник перекладу прецедентного імені. У статті розглядається залежність перекладу прецедентного імені від його зв'язку із джерелом та, відповідно, від ментального образу, що онім активує у відповідному контексті. У той час як деякі прецедентні імена функціонують у культурному просторі незалежно, перетворившись на символи певних характеристик, інші підлягають декодуванню лише на основі прецедентного тексту або ситуації, з яких вони походять. Окрему категорію прецедентних імен становлять оніми, що супроводжуються стереотипним асоціативним комплексом у відповідній спільноті, однак безпосередньо не пов'язані 3 джерелом, тобто культурно специфічний ментальний образ переважає по відношенню до знання джерела походження. Категорія, до якої належить прецедентне ім'я, $є$ суттєвим чинником перекладу, оскільки визначає потребу та обсяг компенсації, яку повинен забезпечити перекладач, якщо онім не є релевантним для цільової культури. Позатекстові коментарі $є$ найбільш продуктивним способом перекладу, оскільки він дає можливість не тільки уникнути пробілів в інтерпретації, а також зберегти культурну специфічність оригіналу. Однак такі коментарі є ефективними, якщо вони є стислими, але при цьому надають максимум інформації, необхідної для розуміння поточного повідомлення, та є достатніми, але не надлишковими.

Ключові слова: вихідна культура, ментальний образ, прецедентне ім'я, прецедентна ситуація, прецедентний текст, спосіб перекладу, цільова культура.

Тащенко А. В. Объем значения как фактор перевода прецедентного имени. В статье рассматривается зависимость перевода прецедентного имени от его связи с источником и, соответственно, от ментального образа, который оним активирует в соответствующем контексте. В то время как некоторые прецедентные имена функционируют в культурном пространстве независимо, превратившись в символы определенных характеристик, другие подлежат декодированию только на основе прецедентного текста или ситуации, из которых они происходят. Отдельную категорию прецедентных имен составляют онимы, сопровождающиеся стереотипным ассоциативным комплексом в соответствующем сообществе, которые, однако, непосредственно не связаны с источником, т. е. культурно специфический ментальный образ превалирует по отношению к знанию источника происхождения. Категория, к которой относится прецедентное имя, является существенным фактором перевода, поскольку определяет потребность и объем компенсации, которую должен обеспечить переводчик, если оним не является релевантным для целевой культуры. Внетекстовые комментарии являются наиболее продуктивным способом перевода, поскольку он дает возможность не только избежать пробелов в интерпретации, но и сохранить культурную специфичность оригинала. Однако такие комментарии являются эффективными, если они сжаты, но при этом предоставляют максимум информации, необходимой для понимания текущего сообщения, будучи достаточной, но не избыточной.

Ключевые слова: исходная культура, ментальный образ, прецедентное имя, прецедентная ситуация, прецедентный текст, способ перевода, целевая культура.

(C) Tashchenko G.V., 2018 


\section{Introduction}

The construction of meaning in the course of communication, whether oral or written, is an important aspect of understanding the message which is a complicated process even for personal interaction. However, while communication is mediated by a translator, interpretation is subject to the same influence. The communicators may be distanced in time, space or both, for this reason the translator's task is to compensate any discrepancies arising from different backgrounds of the author and the reader. It requires broad lingual and cultural competence in order to decode the message and to predict any possible obstacles which may hinder comprehension by a representative of a different culture. Lexical units conveying universal meanings present fewer challenges in comparison to those expressing culture-specific ones not only from the point of view of translation but also from the point of view of their interpretation. Therefore, means of verbalizing cognitive content reserved to a limited number of nations gain increased attention and present a relevant target of $\mathrm{research}$ in Translation Studies. Such phenomena include the precedents names (PNs) as the object of the study which form a class of proper names used out of the original context but activating some characteristics related to the source in the mind of the target reader. The $\mathrm{subject}$ of the $\mathrm{research}$ is represented by the mental image, a PN is based on, as a factor of its translation. Consequently the research is a i med at determining the dependence of the translation method on the nature of the mental image the name actualizes on the bas is of the literary works of the $20^{\text {th }}-21^{\text {st }}$ centuries.

\section{Short review of the latest publications}

Currently, the cognitive approach to the translation process is drawing a growing attention, the researchers are mostly interested in the situations where the differences in the cultural environment provoke certain asymmetry between the linguistic units and the meanings they are supposed to communicate which may be less frequent for the technical terms but rather widespread for metaphorical expressions, including PNs. Translation of the metaphors as such receives a considerable coverage $[3,4,5]$, while the cognitive aspect of PNs as onyms possessing certain characteristics of a metaphor is less well-established from the translational point of view.

A precedent name is so deeply rooted in a particular culture that becomes a "paragon", the most widespread means of conveying a relevant metaphoric meaning deriving from conceptualization of a new object on the basis of a well-known one which is not directly related to the former.

The choice of certain qualities of a person, object or phenomenon which determine the precedence of their names depends on basic values, stereotypes functioning in a specific culture as well as the historical background identifying them. Therefore, various nations or even various periods in the development of the corresponding social community give rise to various PNs which can also lead to differences in the axiological connotations attached to a certain name. The national and cultural differences, on the one hand, allow people to preserve their identity and, on the other, contribute to communicative failures $[1$, p. 3$]$.

For a translator the contrasts inherent in culturespecific linguistic units are of vital importance. However, in case of PNs a translator shall take into account not only cultural discrepancies proper, but also those caused by various "layers" of meaning. Some PNs are so widely recognized that they lose a direct connection with the source becoming, instead, a symbol of a particular quality. They are as easily recalled in the memory of the author as they are in the mind of the reader, since they form the most complete embodiment of the appropriate feature. The PNs falling under this category are mostly used to denote qualities of universal significance: generosity, beauty, honor, greed, maliciousness, etc. For this reason if the PN used in the original is irrelevant in the target culture, the translator may choose between adding an extra- or intratextual commentary in order to explain the meaning, the name is to convey, and replacing it with a name embodying the same characteristic for the representative of the receiving culture. The choice may be based on different factors ranging from political or ideological reasons to personal preferences of the translator.

Another group of PNs covers onyms where underlying mental images are much more complex 
as they constitute a mix of characteristics which are difficult or even impossible to identify as separate. The precedence arises due to a unique mental structure combining a variety of features none of which is dominant. Only the image in its entirety enables the corresponding onym to function as a precedent one thus providing for its gestalt nature. From the translation point of view, such PNs leave virtually no possibilities for substitution because it is highly improbable that the target culture should offer a name with a fully equivalent meaning or at least such a meaning which would prove close enough.

While the first two groups include the names functioning independently though actualization of mental images of various scope, there are some onyms which reveal their meaning only in connection with precedent texts or situations they originate from. PNs possess a rich potential for invoking a wide range of characteristics of a precedent text or a precedent situation critical to a particular society [2], that is why the message containing a PN can be decoded on condition that the recipient knows the "plot", the situation the PN is based on, whether it is real or imaginary.

\section{Results and discussion}

The interpretation of a PN is mostly determined by the degree of its cultural specificity. However, if the translator ideally possesses the background knowledge close to that of a representative of the source culture, the target reader will hardly be competent in all the spheres of life which may be evoked in the text. Consequently, it is crucial to estimate the scope of explanation which is to be provided if the name proves irrelevant for the receiving culture.

In terms of the onyms denoting one characteristic, the authors frequently mention the feature shaping their choice directly. For instance, in the following situation the emptiness of the tomb of one of the most famous Egyptian kings is compared to a restaurant with no visitors where occasional guests feel like mummies.

He only likes 2 or three empty restaurants where nobody goes.

That's right the place he took me last week was like king tuts tomb (Tartt, The Goldfinch, p. 255).

- Він любить ходити лише в ті 2 або 3 порожні ресторани.
- Саме в таке місие він водив мене минулого тижня, я сидів там, як у гробниці тутанхамона (Тартт, Щиголь, переклад В. Шовкуна, с. 418).

Tutankhamun is a pharaoh whose death is covered in mysteries, whose burial place is supposed to be cursed. Numerous researchers have been trying to solve the puzzle over the years contributing to popularization of the image in the mass culture. Not surprisingly, this personality has become known worldwide, therefore, the translation requires no additional explanations.

Nevertheless, certain PNs, though actualizing a single quality, have not acquired the status of precedent ones for the target reader. Thus, the image arising in the mind of the recipient will be incomplete. The most widespread method of compensating for the lack of culture-specific knowledge is addition of a commentary, as shown in the following example. Interestingly, the same person is chosen to be a model of two different qualities, namely wealth and madness. The translator explains that Howard Hughes (1905-1976) was an American industrialist and entrepreneur, innovator and pioneer of aviation, cinema producer and director, one of the richest people of his time. Such a commentary contributes to clarification of the first part of the message where the fortune of the character is compared to that of a business magnate. However, the commentary contains certain excessive information and lacks significance for the second part, as it has no respect to the mental illness underlying Hughes' condition.

He was not as rich as Howard Hughes but not quite as crazy as Hughes had been at the end, either (King, Four Past Midnight).

Він був не настільки багатим, як Говард Г’юз у розквіті своєї кар'єри, та й не настільки схибленим, як Г'юз наприкіниі життя (Кінг, Чотири після півночі с. 841).

The PNs actualizing mental images of gestalt nature also fall into two categories: those preserving their status in the target culture and those losing their functions in the text of translation. However, a PN referring to a complex of features that merge together in order to create a unique, gestalt image leads to complications of both interpretation and translation.

If the PN used by the author is functioning in the target culture with the values pertaining to the 
source PN attached, the mental image it actualizes for the target reader will be preserved. One of the names that gained an international recognition is that of a character of "The Catcher in the Rye" by J. Salinger, Holden Caulfield, who is possibly one of the most controversial protagonists of the Englishlanguage literature of the $20^{\text {th }}$ century.

I gave you that book to read because I thought you would feel identified with him. You're a Holden Caulfield. He doesn't fit anywhere and you don't.

Я тобі дала июо книжку почитати, бо подумала, щз ти відчуєш себе на місиі головного героя. Ти - теж Голден Колфілд. Він нікуди не вписується, так само як ти (Колекиіонер).

A rebel who rejects the privileges of the world he was born into, sharp and cynical, Holden cannot find his place in the world, which serves as the basis for the comparison made by J. Fowles. The mental image, the writer meant to create, combines a wide range of associations rooted in the entire nature of the character, nevertheless, the background knowledge of the target audience will be sufficient to decode the message, as Holden Caulfield has been familiar to them since school years.

Meanwhile the protagonist of a novel by G. du Maurier, Svengali, is less well-known since the writer gained a wider recognition as a cartoonist. The name of Svengali actualizes the image of a manipulator, dominator, exploiter who pretends to help a person, concealing his real intentions. On the one hand, such a mixture of characteristics creates a vivid picture in the mind of the reader of the original. On the other hand, it poses challenges for the translator whose task is to render the name so that it preserved the meaning and the evaluative component pertaining to the source culture.

Now I saw Conchis as a sort of novelist sans novel, creating with people, not words; now I saw him as a complicated but still very dirty old man; now as a Svengali; now as a genius among practical jokers (Fowles, The Magus).

Кончіс уявлявся мені то літераторомпсихіатром, який творить романи не словами на nапері, а людьми в дійсності, то розумним, але дуже розпусним стариганом, то жартівником понад усі жартівники, то втіленням Свенгалі (Фаулз, Маг, переклад О. Короля, с. 199)

Assuming that the PN would be irrelevant for the Ukrainian reader, the translator specifies that
Svengali is an "evil hypnotizer in the "Trilby" novel by George du Maurier". Such a commentary partially explains the choice of the name used for comparison, also mentioning the source of the precedent. In the English-speaking world, Svengali has almost become a common name, even forming derivative expressions such as Svengali defence denoting malpractices in court. However, in translation the commentary provides the Ukrainian audience with sufficient information to avoid gaps in the message perception, adding the source if the readers would like to find out more.

Another issue of translation is constituted by the PNs which preserve their connection with the text or the real situation they originate from, since their meaning can be deciphered only in relation to the source. If it is irrelevant for the target audience, the translator shall provide an explication would be sufficient for interpretation but not be excessively wordy not to distract the reader from the main context.

The following example shows a PN, whose interpretation requires unfolding the basic plot of the corresponding precedent text before the eyes of the reader. The PN "Dr. Jekyll" is not totally unknown in the Ukrainian culture, however, an average Ukrainian reader will probably be unable to decipher the meaning of the onym, since it is rather oriented at a more "competent", educated reader.

There was a corny group shot of four teachers in white lab coats holding bubbling beakers - paging Dr. Jekyll - and below it were four studio shots (King, 11/22/63).

Там містився тривіальний груповий знімок четвірки вчителів у білих лабораторних халатах з клекітливими ретортами в руках - квартетуособлення доктора Джекіла, - а нижче їхні окремі студійні фото (Кінг, 11/22/63, переклад О. Красюка)

As the translator has to take into consideration a broad audience, potentially of various backgrounds, an extra-textual commentary is added, stating that is an "allusion to the plot of a novella by the Scottish writer Robert Louis Stevenson (1850-1894) "The Strange Case of Dr. Jekyll and Mr. Hyde" (1886) which tells a story of a respectable doctor Jekyll who takes a drink he created and is transformed into a cruel executioner, Mr. Hyde". Such a commentary provides an explanation which is brief enough and at 
the same time creates the necessary image of a heterogeneous, controversial group of people.

A similar case is observed with a PN which can be interpreted only against the background of the situation it derives from. Thus, the personality of Adolf Eichinann has created a precedent for the representatives of a certain nation and those who are knowledgeable in the history of the corresponding period. Regarding the Ukrainian audience, they will hardly be able to understand the comparison. Realizing this, the translator takes a decision to reveal the associations accompanying the $\mathrm{PN}$ in the original message: Adolf Eichinann (1906-1962) - a German officer, working in Gestapo, was responsible for "the final decision of the Jew issue". Meanwhile, the role of Adolf Eichinann in the Holocaust is only a part of the explanation required. The PN actualizes the situation covering not only his activity, but also the fact that after he had fled to South America, he was caught, taken to Israel and executed. Therefore, the provided commentary does not include all the aspects of the precedent situation the author refers to, however, it allows making the inferences necessary to fill in the blanks and predict the future events.

"You think," said Oedipa, "then, that they're trying to bring you back to Israel, to stand trial, like they did Eichinann?" (Pynchon, The Crying of Lot 49).

- То ви вважаєте, - сказала Едіпа, - щзо вони намагаються повернути вас до Ізрайлю, щзоб засудити, як Айхмана? (Пінчон, Виголошення лоту 49, переклад М. Нестеєлєєва, р. 132)

Coming from the novels by E. Gardner, the image of Perry Mason achieved the level of precedence due to the prominence in the American cinema. Raymond Burr played this role for an extremely long period of time, from 1957 to 1966 and then from 1985-1993. Not surprisingly, this part has become strongly associated with the creative path of R. Burr. Still, this example is quite illustrative from the point of view of the commentary which has nothing to do with the precedent situation necessary for the onym comprehension in the current context: "Raymond Burr [1917-1993] is an American and Canadian actor who, in 1956, played the role of a journalist, Steve Martin, in "Godzilla: King of the Monsters" [1956], the first "Americanized" version of the
Japanese story. There is some evidence that Pynchon intended to write about Godzilla and his enemies, monsters [e. g. he mentions Mothra Butterfly in his novel "Inherent Vice", 2009]. The decision of the translator in favor of emphasizing R. Burr's role in "Godzilla" is highly questionable, since here the author himself refers to the part chosen for comparison.

"A cash nexus," brooded Oedipa, "you and Perry Mason, two of a kind, it's all you know about, you shysters."

"But our beauty lies," explained Metzger, "in this extended capacity for convolution. A lawyer in a courtroom, in front of any jury, becomes an actor, right? Raymond Burr is an actor, impersonating a lawyer, who in front of a jury becomes an actor (Pynchon, The Crying of Lot 49).

- Фінансові справи, - задумливо промовила Edina, - Це все, щзо ви з Перрі Мейсоном знаєте, обоє рябоє, юристи-авантюристи.

- Але ж наша привабливість якраз і полягає у нашій спритності, - пояснив Метигер. Адвокат у залі суду перед будь-якими присяжними стає актором, так? Реймонд Берр - актор, що видає себе за адвоката, який перед присяжними стає актором (Пінчон, Виголошення лоту 49, переклад М. Нестеєлєєва, c. 29).

Conclusions. Thus, the PN translation is challenging both at the stage of interpretation and transfer for the target reader. It requires substantial linguistic and extralinguistic competence of the translator who is supposed to anticipate the level of background knowledge the target reader should possess and choose the method of translation accordingly. The names which preserve their precedent status in the target culture pose no difficulties, while those losing their relevance lead to the use of transformations aimed to ensure comprehensive understanding of the message. The most wide-spread means of compensation for the lacking component of culture-specific knowledge is an extra-textual commentary added to the text. Nevertheless, its reasonability is determined by the ability of the translator to present the information which is pertinent to the current context, sufficient as well as concise. Otherwise, a perception gap will arise. 
The prospects of the study consist in exploring the influence of the mental image a PN is based on as well as its ties with the source on the onym rendering for the cultures and languages which show more significant discrepancies in terms of the relevant meanings and values.

\section{ЛІТЕРАТУРА}

1. Елисеева С. В. Прецедентные феномены, восходящие к французской культуре, в современной российской и американской прессе: автореф. дис.... канд. филол. наук: спец. 10.02.20 «Сравнительно-историческое, типологическое и сопоставительное языкознание». Екатеринбург, 2010. 23 с. 2. Караулов Ю. Н. Русский язык и языковая личность. М.: Наука, 1987. 264 с. 3. Kövecses Z. Metaphor in Culture. Universality and Variation. Cambridge: New York: Cambridge University Press, 2006. 336 p. 4. Schäffner C. Metaphor in translation. // The Routledge Handbook of Metaphor and Language. London - New York: Routledge, 2017. P. 247-263. 5. Tirkkonen-Condit S. Metaphoric expressions in the translation process // Across Languages and Cultures. Hungary: Akademiai Kiado, 2002. P. 101-116.

\section{ДЖЕРЕЛА ІЛЮСТРАТИВНОГО МАТЕРІАЛУ}

6. Кінг С. 11/22/63 [Електронний ресурс]. Режим доступу : https://javalibre.com.ua/javabook/book/2917141 7. Кінг С. Чотири після півночі. Харків : Книжковий Клуб «Клуб Сімейного дозвілля, 2017. 928 с. 8. Пінчон Т. Виголошення лоту 49. К. : Вид-во Жупанського, 2017. 192 с. 9. Тартт Д. Щиголь. Харків : Книжковий Клуб «Клуб Сімейного Дозвілля», 2016. 16 с. 10. Фаулз Дж. Колекціонер. Харків : Книжний Клуб
«Клуб сімейного дозвілля», 2015. 304 с. 11. Фаулз Дж. Маг. Харків : Книжковий Клуб «Клуб Сімейного Дозвілля», 2016. 528 c. 12. Fowles J. The Collector [Electronic resource]. Access : http://royallib.com/book/

Fowles_John/The_Collector.html. 13. Fowles J. The Magus [Electronic resource]. Access : http://royallib.com/book/Fowles_John/The_Magus.htm 1 14. King S. Four Past Midnight [Electronic resource]. Access :

https://royallib.com/book/King_Stephen/four_past_mid night.html. 15. Pynchon T. The Crying of Lot 49 [Electronic resource]. Access : http://swornfriends.com/Common/ueditor/net/upload/5 1/2013-06-25/ 58 E22E C9BFFED2BF.pdf. 16. Tartt D. The Goldfinch. New-York: Little, Brown and Company, 2013. 494 p.

\section{REFERENCES}

Eliseeva, S.V. (2010). Precedentnye fenomeny, voshodjashhie $k$ francuzskoj kul'ture, v sovremennoj rossijskoj i amerikanskoj presse. Avtoref. diss. dokt. filol. nauk [Precedent phenomena pertaining to the French culture in the Russian and American press]. Ekaterinburg, 23 p. (in Russian).

Karaulov, Ju.N. (1987). Russkij jazyk i jazykovaja lichnost' [Russian language and linguistic identity] Moscow: Nauka (in Russian).

Kövecses, Z. (2006). Metaphor in Culture. Universality and Variation. Cambridge: New York: Cambridge University Press

Schäffner, C. (2017). Metaphor in translation. In: E. Semino (ed.). The Routledge Handbook of Metaphor and Language. New York: Routledge, pp. 247-263.

Tirkkonen-Condit, S. (2002). Metaphoric expressions in the translation process. Across Languages and Cultures, 3(1), 101-116.

Тащенко Ганна Володимирівна - кандидат філологічних наук, доцент кафедри перекладознавства імені Миколи Лукаша Харківського національного університету імені B.H. Каразіна; e-mail: annatashchenko91@gmail.com; ORCID: http://orcid.org/0000-0002-90084935SCHOLAR.GOOGLE:

https://scholar.google.com.ua/citations?user=uc3hgc0AAAAJ\&hl=ru\&citsig=AMstHGQtIY88j1XeKPoWv3 L-u1tO6PRSfg; RESEARCHGATE: https://www.researchgate.net/profile/Anna_Tashchenko 